\title{
A linkage study between HLA and cutaneous malignant melanoma or precursor lesions or both
}

\author{
F DEMENAIS*, J P CESARINI $\dagger$, M DAVEAU $\ddagger$, B CAVELIER $\S, J$ GONY $\|$, \\ N FEINGOLD*, AND J HORS $\|$
}

From*Unité de Recherche de Génétique Epidémiologique, INSERM U155, Château de Longchamp, Bois de Boulogne, 75016 Paris; $\nmid$ Laboratoire de Recherche sur les Tumeurs de la Peau Humaine, INSERM, Fondation Rothschild, 25 Rue Manin, 75019 Paris; $\ddagger$ Unité de Recherches sur la Génétique des Protéines, INSERM U78, 543 Chemin de la Bretèque, Bois Guillaume, 76230 Rouen; §Centre de Transfusion Sanguine, 609 Chemin de la Bretèque, Bois Guillaume, 76230 Rouen; and \|Laboratoire d'Histocompatibilité, Centre Hayem, INSERM U93, Hôpital Saint-Louis, 2 Place du Dr Fournier, 75475 Paris Cédex 10, France.

SUMMARY In seven pedigrees displaying the familial atypical multiple mole-melanoma (FAMMM) syndrome, three successive linkage analyses were performed between HLA and an assumed dominant gene determining respectively each of the following affected phenotypes: (1) precursor lesions, (2) cutaneous malignant melanoma (CMM), and (3) precursor lesions or CMM or both. Close linkage could be excluded in (1) and (3). However, if the transmission of malignant melanoma itself were assumed to be due to a single gene different from the one responsible for precursor lesions, a maximum lod score of 1.64 was observed at a recombination fraction of $5 \%$, assuming low penetrance values. These different results are discussed in respect to the possible mechanisms causing the familial distribution of these traits. Two alternative hypotheses were proposed. Either the FAMMM syndrome is a rare genetic entity not closely linked to HLA or the association and transmission of precursor lesions and CMM in families are due to several factors among which HLA might play a role.

Familial occurrence of cutaneous malignant melanoma (CMM) has been widely reported since the first report in 1817 cited by Greene and Fraumeni. ${ }^{1}$ The frequency of familial malignant melanoma cases among all occurrences of the disease varies from 4 to $12 \%$ according to the authors. Various examples of vertical transmission of CMM in families have been described, fitting a dominant mode of inheritance. However, in other series, irregular transmission patterns have suggested reduced penetrance of a dominant gene or a polygenic mechanism. ${ }^{1}$ Recently, among familial malignant melanoma cases, a new clinical entity associated with precursor lesions has been isolated ${ }^{2-4}$ : atypical moles have been found in CMM patients belonging to multiple case families and their relatives. This new syndrome is known as B-K mole ${ }^{2}$ or familial atypical multiple molemelanoma (FAMMM) syndrome. ${ }^{4}$ In these studies, familial transmission of this syndrome appeared to be consistent with autosomal dominant inheritance.

As in other pre-cancerous conditions, it seemed

Received for publication 11 July 1983.

Accepted for publication 14 February 1984. interesting to seek for a biological marker which would allow detection of high risk persons. Some cellular biomarkers which might be associated with CMM have been reviewed by Lynch et al. ${ }^{5}$ An increased frequency of $\mathrm{Gm}(+2)$ immunoglobulin allotype in CMM patients was reported once, ${ }^{6}$ but not found in another study. ${ }^{7}$ Recently, Greene et al, ${ }^{8}$ analysing 14 FAMMM kindreds, did not find any evidence for linkage between a dominant gene for CMM itself and 23 genetic markers (not including HLA). However, they suggested a possible loose linkage between a dominant gene for precursor lesions or CMM or both and the $\mathrm{Rh}$ locus (maximum lod score of 2.00 at a recombination fraction of $30 \%$ ).

The search for association between susceptibility to CMM and HLA antigens has lead to numerous population studies, but with no significant results in most of them. ${ }^{9}$ However, a significant increase in HLA-B40 and a decrease in HLA-Bw35 antigens have been recently reported in a series of 140 melanoma patients when compared to controls. ${ }^{10}$ A significant increase of HLA-A9 was also observed 
in severe forms of the disease, especially in the metastatic or relapsing forms. ${ }^{11}$ An indication of a possible linkage between a dominant CMM susceptibility gene and HLA has been suggested in a large Australian kindred, ${ }^{12}$ with a maximum lod score of 1.25 at a recombination distance of 10 units. Furthermore, in five of six Italian families with multiple cases of CMM, affected sibs were reported to share at least one HLA haplotype. ${ }^{13}$

We present here a linkage analysis between HLA and precursor lesions or CMM or both in seven families displaying the FAMMM syndrome.

\section{Patients and methods}

\section{PATIENTS}

Since 1978, about 350 malignant melanoma patients seen by one of us ( J P Cesarini) were questioned about the presence of similar lesions among their relatives. Seven of them with a positive family history were selected and clinical and later histological investigation of their family members was performed. As seen in figs 1 and 2, six of these seven CMM probands had precursor lesions, the 'mole pattern'. Among 54 of their blood relatives who were examined and HLA typed, 21 had precursor lesions and melanocytic dysplasia could be demonstrated histologically in seven of 13 skin biopsied cases. The presence of atypical moles was also documented in five dead persons, making a total of 26 relatives with precursor lesions. Malignant melanoma developed in nine of these relatives showing a mole pattern and was found in five other cases (four of them dead) without diagnosed precursor lesions.

Clinically, the mole pattern displayed the features usually described..$^{2-4}$ Histology showing dysplastic melanocytes confirmed the diagnosis of the FAMMM syndrome. However, skin biopsy may not always demonstrate dysplasia since, in a single patient, some moles are atypical while others are normal. Primary malignant melanoma cases showed the usual histopathology with a majority of lateral superficial spreading component.

\section{HLA TYPING}

Blood samples of the members of these seven families were taken for HLA typing after their consent. Thirteen alleles of HLA-A, 18 of B, and
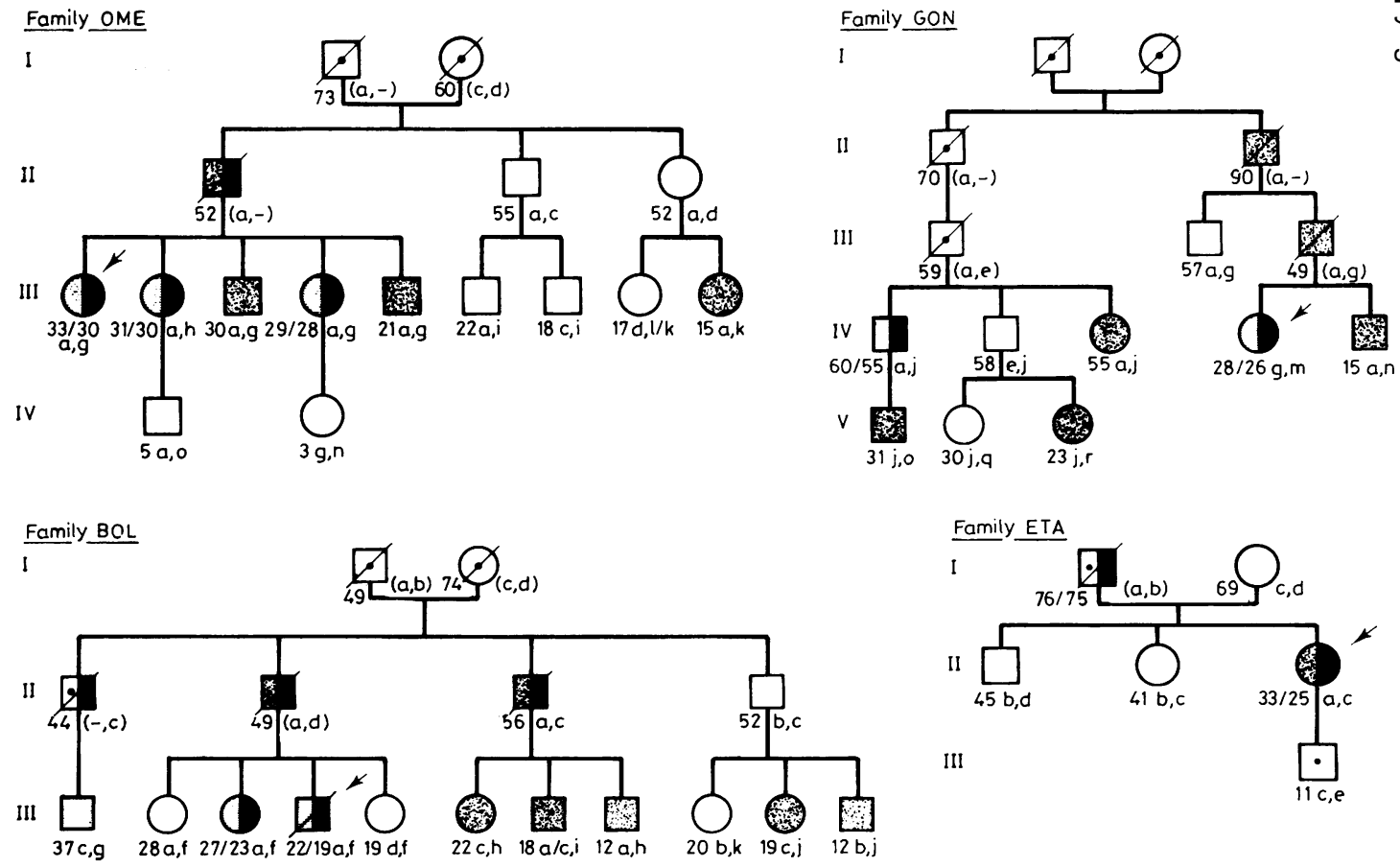

FIGS 1 and 2 Pedigrees of the seven families. The pedigrees have been simplified since spouses of family members and subjects of the youngest generation who were not HLA typed are not shown. HLA haplotypes are indicated by letters and deduced HLA haplotypes are in parentheses. The figures indicate the present age/age at diagnosis. 


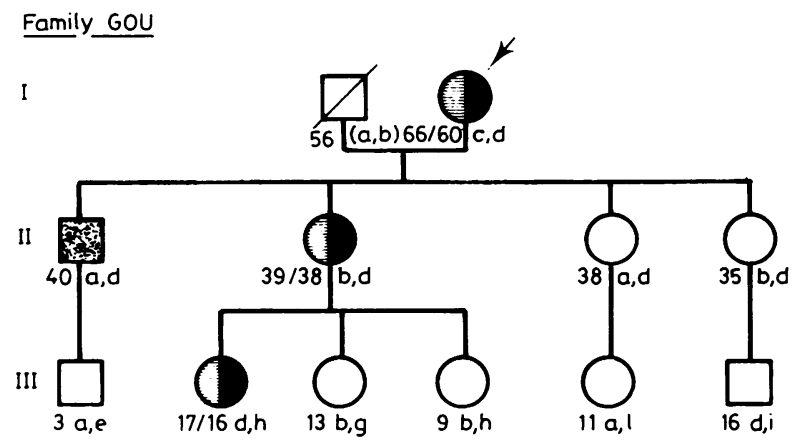

Family CHA
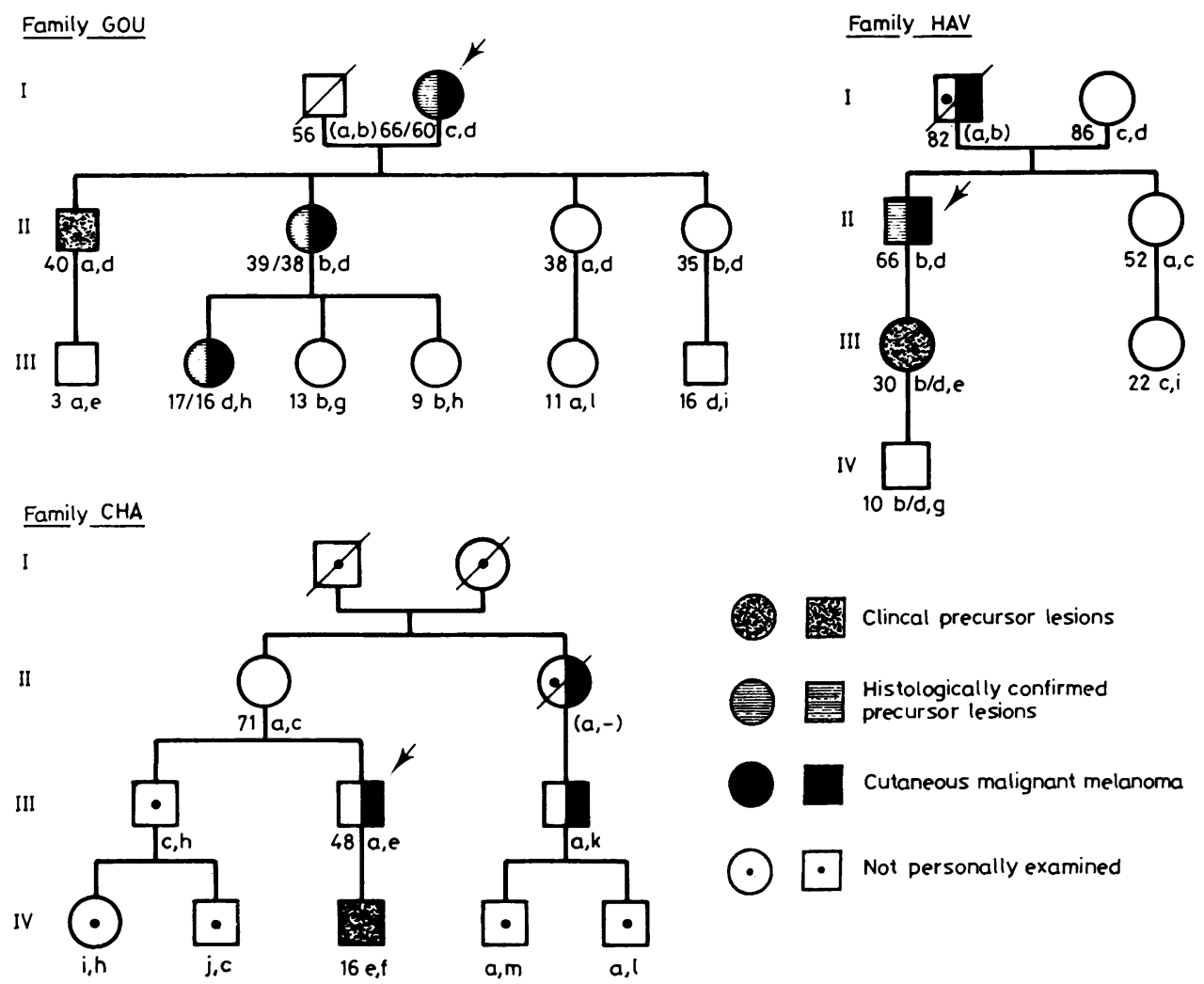

FIG 2 See fig 1 .

eight of $\mathrm{C}$ locus were tested by microlymphocytotoxicity ${ }^{14}$ on peripheral lymphocytes. Seven HLADR alleles were tested on enriched B cell suspensions after depletion of $T$ rosette forming cells with sheep erythrocytes. Bf (Properdine factor B) alleles were determined using the technique of Alper et al ${ }^{15}$ on fresh samples of sera stored at $-80^{\circ} \mathrm{C}$. The nomenclature used for designation of the HLA antigens is that of the VIIIth International Workshop. ${ }^{16}$

\section{LINKAGE ANALYSIS}

Possible linkage between an assumed dominant gene controlling the susceptibility to the disease and HLA was investigated by the lod score method for the seven families. It is not certain that a single genetic mechanism is responsible for precursor lesions or the malignant state or both. Therefore, three successive linkage analyses were performed considering each of the following as the affected phenotype: (1) only persons with precursor lesions (with or without CMM) are affected; (2) only persons displaying malignant melanoma are affected; (3) all persons showing any of the clinical forms (precursor lesions or CMM or both) are affected. Each of these traits was assumed to be determined by a single autosomal dominant gene. The lod scores were computed for different values of the gene frequency and penetrance corresponding to a population frequency of the trait taken to be either 1 in 1000 or 1 in 10000 for precursor lesions (since it is not known precisely) and 1 in 100000 for CMM. ${ }^{17}$ The third analysis was performed at two values of the disease frequency: 1 in 1000 and 1 in 100000 . As the age of onset of these traits is variable, penetrances of susceptible genotypes were calculated for each subject as a function of age, using a straight line age correction as proposed by Hodge et al. ${ }^{18}$ We used a linear age correction curve with the penetrance varying from $0 \%$ to a maximal value between 3 and 30 years for trait (1), 15 and 40 years for trait (2), and 3 and 40 years for trait (3). Differept maximal penetrances were considered: $0 \cdot 05,0 \cdot 10,0 \cdot 30,0 \cdot 50,0 \cdot 70$, and $0 \cdot 90$. Since there are three intra-HLA recombinants (two between A and B and one between B and DR loci), the data were analysed twice considering 
separately the HLA-A locus and the remaining HLA-C-B-DR haplotype*. Lod scores were calculated for equal male and female recombination

*For the B-DR recombinant, we considered the segregation of the DR locus alone in parents and offspring. This could not change the results since both parents were heterozygous for DR.

TABLE 1 HLA haplotypes in patients with precursor lesions $(P L)$ or cutaneous malignant melanoma (CMM) or both in the seven families.

\begin{tabular}{|c|c|c|c|c|c|c|c|c|}
\hline \multirow[t]{2}{*}{ Family } & \multirow[t]{2}{*}{$\begin{array}{l}\text { HLA } \\
\text { haplotype }\end{array}$} & \multirow[t]{2}{*}{$A$} & \multirow[t]{2}{*}{$C$} & \multirow[t]{2}{*}{$\boldsymbol{B}$} & \multirow[t]{2}{*}{$D R$} & \multirow[t]{2}{*}{$B f$} & \multicolumn{2}{|c|}{$\begin{array}{l}\text { No of patients } \\
\text { with the } \\
\text { haplotype }\end{array}$} \\
\hline & & & & & & & $P L$ & $C M M$ \\
\hline \multirow[t]{3}{*}{ ETA } & $a^{*}$ & w24 & w7 & 8 & 4 & NT & 1 & 2 \\
\hline & $b$ & 3 & w5 & 12 & NT & NT & 0 & 1 \\
\hline & $c^{*}$ & 1 & w1 & w35 & 5 & NT & 1 & 1 \\
\hline \multirow[t]{7}{*}{ GON } & $\mathbf{a}$ & w33 & - & 14 & 4 & NT & 5 & 1 \\
\hline & $\mathrm{g}^{*}$ & 2 & w3 & 15 & - & NT & 2 & 1 \\
\hline & $\mathbf{j}$ & w24 & 一 & - & 7 & NT & 4 & 1 \\
\hline & $\mathrm{m}^{*}$ & 2 & w4 & w35 & 3 & NT & 1 & 1 \\
\hline & $\mathbf{n}$ & w24 & w2 & 18 & 4 & NT & 1 & 0 \\
\hline & 0 & 29 & - & 12 & 4 & $\mathrm{NT}$ & 1 & 0 \\
\hline & $r$ & 3 & w4 & w35 & 4 & $\mathrm{NT}$ & 1 & 0 \\
\hline \multirow[t]{8}{*}{ BOL } & $a^{*}$ & 29 & - & w44 & 7 & F & 5 & 4 \\
\hline & $\mathbf{b}$ & - & - & 7 & 2 & $\mathbf{S}$ & 1 & 0 \\
\hline & c & 2 & - & 5 & 5 & $\mathbf{F}$ & 4 & 2 \\
\hline & d & 1 & w3 & 40 & w6 & $\mathbf{S}$ & 1 & 1 \\
\hline & $f^{*}$ & w23 & w7 & w21 & 5 & $\mathbf{S}$ & 2 & 2 \\
\hline & $\mathrm{g}$ & w192 & w1 & w44 & 2 & NT & 1 & 0 \\
\hline & $\mathrm{h}$ & w32 & - & 14 & 1 & $\mathbf{S}$ & 2 & 0 \\
\hline & $\mathrm{j}$ & w23 & - & 17 & 5 & $\mathbf{S}$ & 2 & 0 \\
\hline \multirow[t]{4}{*}{ OME } & $a^{*}$ & w32 & NT & 7 & NT & NT & 7 & 4 \\
\hline & $\mathrm{g}^{*}$ & 2 & NT & w21 & NT & NT & 4 & 2 \\
\hline & h & w24 & NT & 7 & NT & NT & 1 & 1 \\
\hline & $\mathbf{k}$ & 28 & NT & 27 & NT & NT & 1 & 0 \\
\hline \multirow[t]{4}{*}{ CHA } & $a^{*}$ & 3 & - & 7 & 2 & NT & 0 & 3 \\
\hline & $\mathrm{e}^{*}$ & 2 & w7 & 8 & 3 & NT & 1 & 1 \\
\hline & f & 11 & w1 & 47 & 5 & NT & 1 & 0 \\
\hline & $\mathbf{k}$ & 1 & w2 & 40 & w6 & NT & 0 & 1 \\
\hline \multirow[t]{4}{*}{ HAV } & $a$ & 2 & w2 & 12 & - & NT & 0 & 1 \\
\hline & $\mathrm{b}^{*}$ & w24 & w7 & w39 & 1 & NT & $2-1 \dagger$ & 2 \\
\hline & $\mathrm{d}^{*}$ & 11 & w4 & w35 & - & NT & $1-2 \dagger$ & 1 \\
\hline & $\mathrm{e}$ & 3 & - & 8 & - & NT & 1 & 0 \\
\hline \multirow[t]{5}{*}{ GOU } & $\mathbf{a}$ & 2 & NT & 12 & w3 & NT & 1 & 0 \\
\hline & b & 2 & NT & 17 & 7 & $\mathbf{N T}$ & $i$ & 1 \\
\hline & $c^{*}$ & 10 & NT & 7 & NT & NT & 1 & 1 \\
\hline & $d^{*}$ & 11 & w4 & w35 & 1 & NT & 4 & 3 \\
\hline & h & 2 & NT & 15 & NT & NT & 1 & 1 \\
\hline
\end{tabular}

*Haplotypes present in probands.

†Recombinant between $\mathrm{A}$ and $\mathrm{C}$ locus. NT Not tested. values $(\theta)$ varying from $0 \cdot 0$ to 0.40 using the com- $\stackrel{\mathbb{D}}{\stackrel{\Phi}{(}}$ puter programme LIPED ${ }^{19}$ modified to allow for variable age of onset of the disease. ${ }^{18}$

\section{Results}

As seen in figs 1 and 2, precursor lesions and CMM are each vertically transmitted over two or three generations, which may suggest a dominant pattern of inheritance with incomplete penetrance in these seven families.

HLA haplotype assessment was clearly established in each family. The HLA haplotypes of affected persons are listed in table 1. We can note that Aw24, a split of A9, was present in two of the seven probands, four probands had Bw35, and none had B40, which is not in accordance with reported associations in case-control series (see introduction). The HLA haplotypes segregated in a normal codominant manner. However, three recombinants, two between A and B and one between B and DR loci, were observed: in two healthy subjects (families BOL and OME, generation III) and in one patient with precursor lesions (family $\mathrm{HAV}$, generation III).

All the lod scores are given for the HLA-C-B-DRg part of the haplotype, the results from the A locus being similar. They are presented in tables 2,3 , an 4 respectively for the three traits defined previously: When precursor lesions are considered, none of the lod scores is positively significant (table 2). Tight linkage can be excluded (lod score $<-2 \cdot 0$ ) if the gene frequency is less than or equal to $2 \times 10^{-3}$. The distance $(0 \%, 5 \%$, or $10 \%$ recombination) at which exclusion of linkage can be asserted depends on the values of gene frequency and penetrance. When this analysis was repeated by taking as affected only those with histologically confirmed precursor lesions, it was possible to exclude linkage only at a recombination fraction of $0 \%$.

Similar results were obtained when the trait

TABLE 2 Lod scores for linkage between a dominant gene for precursor lesions and HLA.

\begin{tabular}{|c|c|c|c|c|c|c|c|}
\hline \multirow[t]{2}{*}{ Maximal penetrance at 30 years } & \multirow[t]{2}{*}{ Gene frequency (q) } & \multicolumn{6}{|c|}{ Recombination fraction $(\theta)$} \\
\hline & & $0 \cdot 0$ & 0.05 & $0 \cdot 10$ & $0 \cdot 20$ & $0 \cdot 30$ & 0.40 \\
\hline \multirow[t]{2}{*}{0.05} & $10^{-2}$ & -0.26 & 0.64 & 0.71 & 0.56 & 0.36 & 0.13 \\
\hline & $10^{-3}$ & $-3 \cdot 75$ & -1.00 & -0.57 & 0.06 & 0.26 & 0.14 \\
\hline \multirow[t]{2}{*}{$0 \cdot 10$} & $5 \times 10^{-3}$ & $-1 \cdot 31$ & 0.13 & 0.29 & 0.35 & 0.31 & 0.13 \\
\hline & $5 \times 10^{-4}$ & -5.04 & $-1 \cdot 59$ & -0.94 & -0.03 & 0.23 & 0.13 \\
\hline \multirow[t]{2}{*}{$0 \cdot 30$} & $2 \times 10^{-3}$ & $-3 \cdot 59$ & -1.05 & -0.62 & -0.03 & 0.20 & 0.12 \\
\hline & $2 \times 10^{-4}$ & $-7 \cdot 51$ & -2.63 & -1.45 & -0.19 & 0.18 & 0.12 \\
\hline \multirow[t]{2}{*}{0.50} & $10^{-3}$ & $-5 \cdot 39$ & -1.99 & $-1 \cdot 25$ & -0.26 & 0.13 & 0.11 \\
\hline & $10^{-4}$ & -9.36 & $-3 \cdot 31$ & $-1 \cdot 80$ & -0.34 & 0.12 & 0.11 \\
\hline \multirow[t]{2}{*}{0.70} & $7 \times 10^{-4}$ & $-7 \cdot 58$ & -3.05 & -1.90 & -0.50 & 0.05 & 0.10 \\
\hline & $7 \times 10^{-5}$ & $-11 \cdot 57$ & $-4 \cdot 10$ & $-2 \cdot 27$ & -0.54 & 0.05 & 0.10 \\
\hline \multirow[t]{2}{*}{0.90} & $6 \times 10^{-4}$ & $-11 \cdot 64$ & $-4 \cdot 62$ & $-2 \cdot 79$ & -0.80 & -0.03 & 0.09 \\
\hline & $6 \times 10^{-5}$ & $-15 \cdot 63$ & -5.46 & -3.06 & -0.83 & -0.04 & 0.09 \\
\hline
\end{tabular}


TABLE 3 Lod scores for linkage between a dominant gene for malignant melanoma and HLA.

\begin{tabular}{|c|c|c|c|c|c|c|c|}
\hline \multirow[t]{2}{*}{ Maximal penetrance at 40 years } & \multirow[t]{2}{*}{ Gene frequency $(q)$} & \multicolumn{6}{|c|}{ Recombination fraction $(\theta)$} \\
\hline & & 0.0 & 0.05 & $0 \cdot 10$ & $0 \cdot 20$ & $0 \cdot 30$ & 0.40 \\
\hline $\begin{array}{l}0.05 \\
0.10 \\
0.30 \\
0.50 \\
0.70 \\
0.90\end{array}$ & $\begin{array}{l}10^{-4} \\
5 \times 10^{-5} \\
2 \times 10^{-5} \\
10^{-5} \\
7 \times 10^{-6} \\
6 \times 10^{-6}\end{array}$ & $\begin{array}{l}-0.13 \\
-0.48 \\
-1.21 \\
-1.92 \\
-3.01 \\
-5.59\end{array}$ & $\begin{array}{l}1.64 \\
1.64 \\
1.58 \\
1.43 \\
1.13 \\
0.59\end{array}$ & $\begin{array}{l}1.56 \\
1.56 \\
1.54 \\
1.47 \\
1.33 \\
1.09\end{array}$ & $\begin{array}{l}1 \cdot 11 \\
1 \cdot 11 \\
1 \cdot 13 \\
1 \cdot 13 \\
1 \cdot 13 \\
1 \cdot 10\end{array}$ & $\begin{array}{l}0.59 \\
0.60 \\
0.62 \\
0.65 \\
0.67 \\
0.70\end{array}$ & $\begin{array}{l}0.20 \\
0.20 \\
0.21 \\
0.23 \\
0.25 \\
0.26\end{array}$ \\
\hline
\end{tabular}

TABLE 4 Lod scores for linkage between a dominant gene for precursor lesions or malignant melanoma or both and $H L A$.

\begin{tabular}{|c|c|c|c|c|c|c|c|}
\hline \multirow[t]{2}{*}{ Maximal penetrance at 40 years } & \multirow[t]{2}{*}{ Gene frequency (q) } & \multicolumn{6}{|c|}{ Recombination fraction $(\theta)$} \\
\hline & & 0.0 & 0.05 & $0 \cdot 10$ & $0 \cdot 20$ & $0 \cdot 30$ & 0.40 \\
\hline 0.05 & $\begin{array}{l}10^{-2} \\
10^{-4}\end{array}$ & $\begin{array}{l}-2.35 \\
-13.73\end{array}$ & $\begin{array}{l}-0.54 \\
-4.01\end{array}$ & $\begin{array}{l}-0.10 \\
-2.26\end{array}$ & $\begin{array}{r}0.09 \\
-0.59\end{array}$ & $\begin{array}{r}0.07 \\
-0.08\end{array}$ & $\begin{array}{l}-0.02 \\
-0.03\end{array}$ \\
\hline $0 \cdot 10$ & $\begin{array}{l}5 \times 10^{-3} \\
5 \times 10^{-5}\end{array}$ & $\begin{array}{r}3.99 \\
-15.68\end{array}$ & $\begin{array}{l}-1 \cdot 15 \\
-4.35\end{array}$ & $\begin{array}{l}-0.56 \\
-2.34\end{array}$ & $\begin{array}{l}-0.13 \\
-0.61\end{array}$ & $\begin{array}{r}0.01 \\
-0.09\end{array}$ & $\begin{array}{l}-0.02 \\
-0.03\end{array}$ \\
\hline 0.30 & $\begin{array}{l}2 \times 10^{-3} \\
2 \times 10^{-5}\end{array}$ & $\begin{array}{r}-7.28 \\
-19.18\end{array}$ & $\begin{array}{l}-2 \cdot 30 \\
-4 \cdot 75\end{array}$ & $\begin{array}{l}-1.42 \\
-2.47\end{array}$ & $\begin{array}{l}-0.46 \\
-0.66\end{array}$ & $\begin{array}{l}-0.07 \\
-0.10\end{array}$ & $\begin{array}{l}-0.02 \\
-0.02\end{array}$ \\
\hline 0.50 & $\begin{array}{l}10^{-3} \\
10^{-5}\end{array}$ & $\begin{array}{r}9.61 \\
-21.56\end{array}$ & $\begin{array}{l}-3.08 \\
-5.01\end{array}$ & $\begin{array}{l}-1.93 \\
-2.62\end{array}$ & $\begin{array}{l}-0.63 \\
-0.73\end{array}$ & $\begin{array}{l}-0.11 \\
-0.13\end{array}$ & $\begin{array}{l}-0.02 \\
-0.02\end{array}$ \\
\hline 0.70 & $\begin{array}{l}7 \times 10^{-4} \\
7 \times 10^{-6}\end{array}$ & $\begin{array}{l}-12 \cdot 11 \\
-24 \cdot 09\end{array}$ & $\begin{array}{l}-3.88 \\
-5.39\end{array}$ & $\begin{array}{l}-2.40 \\
-2.87\end{array}$ & $\begin{array}{l}-0.78 \\
-0.84\end{array}$ & $\begin{array}{l}-0.15 \\
-0.16\end{array}$ & $\begin{array}{l}-0.02 \\
-0.02\end{array}$ \\
\hline 0.90 & $\begin{array}{l}6 \times 10^{-4} \\
6 \times 10^{-6}\end{array}$ & $\begin{array}{l}-15.97 \\
-27.95\end{array}$ & $\begin{array}{l}-4.95 \\
-6 \cdot 18\end{array}$ & $\begin{array}{l}-2.99 \\
-3.36\end{array}$ & $\begin{array}{l}-0.97 \\
-1.01\end{array}$ & $\begin{array}{l}-0.19 \\
-0.19\end{array}$ & $\begin{array}{l}-0.01 \\
-0.01\end{array}$ \\
\hline
\end{tabular}

analysed is precursor lesions or CMM or both. As seen in table 4 , all the lod scores were negative. Linkage can be firmly excluded at a distance $\leqslant 10 \%$ recombination for the different values of penetrance and gene frequency corresponding to a prevalence of 1 in 100000 . When the gene frequency is a hundred times greater (prevalence of 1 in 1000), it is also possible to exclude linkage but at lower $\boldsymbol{\theta}$ values.

When the linkage analysis was performed between HLA and malignant melanoma itself, very few lod scores reached negative values (table 3). Only absence of recombination $(\theta=0.0)$ can be excluded, assuming high penetrance $(0.70$ or 0.90$)$ and very low gene frequency. The highest scores are obtained at $\theta$ values of $5 \%$ to $10 \%$. The maximum observed lod score is 1.64 at a recombination fraction of $5 \%$ when the maximal penetrance is 0.10 or 0.05 and the gene frequency is $5 \times 10^{-5}$ or $10^{-4}$ respectively; it remains almost unchanged by a hundred-fold increase in the gene frequency. This lod score value, although not significant since it is smaller than the lod of at least 3.0 required to establish linkage, may indicate a trend in favour of possible linkage.

In each case, linkage homogeneity among these seven families was tested by a $\chi^{2}$ with 6 degrees of freedom; it was not significant.

\section{Discussion}

Segregation analysis, which allows discrimination between several transmission hypotheses for the disease, could not be performed here since it was not possible to correct accurately for ascertainment. It is well known that misspecified ascertainment can lead to biased estimates of the parameters of the genetic model. A dominant pattern of inheritance was assumed, since precursor lesions and CMM appeared to be vertically transmitted in these families, and is in agreement with previous published reports (see introduction). Since the parameters at the disease locus, gene frequency and penetrance, were not precisely known, various sets of these parameters were considered. It has been recently shown by Clerget-Darpoux et $a l^{20}$ that false parameter values at the disease locus can lead to biased estimates of the recombination fraction but do not greatly affect the maximum lod score value.

These different linkage analyses allow exclusion of close linkage between HLA and a gene assumed to determine either precursor lesions (trait 1) or any of the clinical forms, precursor lesions or CMM or both (trait 3 ), when the gene frequency is $\leqslant 10^{-3}$. However, there is an indication of a possible linkage between HLA and CMM if the malignant state is assumed to 
be itself determined by a single gene, different from the one responsible for precursor lesions. It would be inaccurate to add these lod scores obtained between CMM and HLA to those which could be computed from the published Australian ${ }^{12}$ and Italian ${ }^{13}$ family data since the familial transmission of CMM in these different sets of data may not be due to a ubiquitous genetic mechanism. Firstly, the frequency of CMM is much higher in Australia ${ }^{12}$ (1 in 1000) than in Europe (taken here to be 1 in 100000 ) and, secondly, information concerning precursor lesions was not mentioned in the Australian and Italian families.

Thus, the interpretation of our results depends on the possible genetic mechanisms assumed to control the association and transmission of both traits, precursor lesions and CMM, in families. We propose here two hypotheses. (a) There is a rare single gene, with variable expressivity, determining precursor lesions or CMM or both which is not closely linked to HLA. In this case, the lod score of 1.64 observed between CMM and HLA would be due to chance. (b) There is a more complex mechanism involving several factors, genetic and environmental, interacting with the gene determining precursor lesions to cause the neoplastic transformation. In this case, the precursor lesion gene is not closely linked to HLA and the lod score of 1.64 between HLA and CMM reflects a possible role of the HLA complex in the development of malignancy.

Previous genetic studies of precursor lesions and CMM, considered together or separately, do not allow a clear discrimination between these two hypotheses. A formal segregation analysis was recently performed in 14 large families with multiple cases of $\mathbf{C M M}$ and dysplastic naevi. ${ }^{8}$ The transmission of CMM was found to be compatible with dominant inheritance. However, Mendelian segregation at one locus for dysplastic naevi or CMM or both did not fit the data and this could have been due to the presence of sporadic phenocopies, an undetected ascertainment bias, or genetic heterogeneity. ${ }^{8}$ As mentioned previously, a possible but not significant loose linkage between an assumed dominant gene for dysplastic naevi or CMM or both and the $R h$ locus was observed in that sample. ${ }^{8}$ When CMM was analysed separately, no such result was obtained with $\mathrm{Rh}$ or any other marker investigated. We also noted that linkage was not excluded with the GLO (glyoxalase) locus located close to the HLA region. The difference in the results between the two linkage analyses according to the trait studied, precursor lesions* or the malignant state, is in accordance with our observations and tends to

\footnotetext{
* The two traits, precursor lesions or precursor lesions or CMM or both, would probably lead to the same results since $92 \%$ of CMM cases examined had precursor lesions in that sample. 8
}

favour our second hypothesis of different genetic $\stackrel{\mathbb{D}}{\vec{D}}$ mechanisms for precursor lesions and the neoplastic transformation. Besides these familial clusters of $\overrightarrow{\vec{\omega}}$ precursor lesions, sporadic cases, with or without $-\overrightarrow{0}$ melanoma, have also been described ${ }^{21} 22$ and a $\frac{C}{\sigma}$ possible polygenic inheritance was recently discussed $\frac{\bar{\omega}}{\bar{\omega}}$ by Happle et al. ${ }^{23}$ With regard to the genetic deter- $\widetilde{\Phi}$ mination of CMM considered as a whole, not only 2 monogenic ${ }^{1}$ but also polygenic inheritance ${ }^{24}{ }^{25}$ has $ळ$ been proposed. Furthermore, environmental factors $\overrightarrow{0}$ may also contribute to familial aggregation of $\vec{\overrightarrow{ }}$ malignant melanoma, such as ultraviolet radiation, $\vec{\omega}$ hormonal changes, oncogenic viruses, or carcinogenic chemicals. ${ }^{26}$ In particular, a possible role of aco virus has been mentioned by several authors ${ }^{27}$ and $\mathrm{N}_{-}$ immunological tests were found to be abnormal $\sigma$ s among various members of families with the $\overrightarrow{\mathrm{N}}$ FAMMM syndrome when compared to non-family 0 controls. ${ }^{5}$ If the HLA region is confirmed by other 을 studies to influence the susceptibility to CMM, and in the light of the viral hypothesis, one can speculate ${ }_{\mathbb{D}}$ that immune response genes may be involved, $\overparen{\varnothing}$ following the murine virus induced leukaemia 3 model $^{28}$ and the MHC restriction lysis. ${ }^{29}$ Thus, $\underset{\text { D }}{ }$ linkage studies, especially with the HLA and $R h \cdot \vec{~}$ loci, should be pursued, and immunological tesfs $\infty$ are needed which could eventually allow beter ${ }^{+}$ understanding of the familial aggregation of pre cursor lesions and malignant melanoma.

We are grateful to Dr C Bonaïti for her helpful $\stackrel{2}{\circledR}$ comments and advice. This work was supported by a $\overrightarrow{\overrightarrow{0}}$ grant from GEFLUC 1982-83 and a grant from 3 Caisse Nationale de l'Assurance Maladie des Travailleurs Salariés (CNAMTS). It was also financed by $\mathrm{U} 212$ dotation and la Ligue Française contre le Cancer.

\section{References}

1 Greene MH, Fraumeni JF. The hereditary variant of 0 malignant melanoma. In: Clark WH, Goldman MJ, Mastrangelo MJ, eds. Human malignant melanoma. New $D$ York: Grune and Stratton, 1979:139-66.

2 Clark WH, Reimer RR, Greene M, et al. Origin of familial malignant melanomas from heritable melanocytic lesions. $\sigma$ Arch Dermatol 1978;114:732-8.

3 Reimer RR, Clark WH, Greene MH, et al. Precursor ${ }^{\circ}$ lesions in familial melanoma. A new genetic preneoplastic $\omega$ syndrome. JAMA 1978;239:744-6.

- Lynch HT, Frichot BC, Lynch JF. Familial atypical

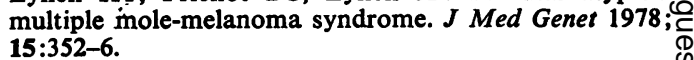

- Lynch HT, Fusaro RM, Danes BS, et al. A review of ${ }^{+}$ hereditary malignant melanoma including biomarkers in $\square$ familial atypical multiple mole melanoma syndromo. Cancer Genet Cytogenet 1983;8:325-58. 
- Jorgensen G, Lal VB. Serogenetic investigations on malignant melanomas with reference to the incidence of ABO system, Rh system, Gm, Inv, $\mathrm{Hp}$ and $\mathrm{Gc}$ systems. Humangenetik 1972;15:227-31.

7 Schultheis W, Peter HH, Deicher H. Gm(1) and Gm(2) immunoglobulin allotypes in patients with malignant melanoma. Humangenetik $1975 ; 28: 177-81$.

- Greene MH, Goldin LR, Clark WH, et al. Familial cutaneous malignant melanoma: autosomal dominant trait possibly linked to the Rh locus. Proc Natl Acad Sci USA 1983;80:6071-5.

- Ryder LP, Andersen E, Svejgaard A. HLA and disease registry. Copenhagen: Munksgaard, 1979.

10 Pellegris G, Illeni MT, Vaglini M, et al. HLA antigens in malignant melanoma patients. Tumori 1980;66:51-8.

11 Cavelier B, Daveau M, Gilbert D, et al. Augmentation de l'antigène HLA-A9 dans les mélanomes malins principalement dans les formes métastatiques ou les récidives. A propos de 105 mélanomes dont 34 formes graves. $C R$ Acad Sci [D] (Paris) 1980;291:241-3.

12 Hawkins BR, Dawkins RL, Hockey A, et al. Evidence for linkage between HLA and malignant melanoma. Tissue Antigens 1981 ;17:540-1.

13 Pellegris G, Illeni MT, Rovini D, et al. HLA complex and familial malignant melanoma. Int J Cancer 1982;29: 621-3.

16 Mital KK, Mickey MR, Singal DP, Terasaki PT. Refinement of microdroplet lymphocyte cytotoxicity test. Transplantation 1968;6:923-7.

15 Alper CA, Boenisch T, Wastson L. Genetic polymorphism in human glycine rich B glycoprotein. J Exp Med 1972;135:68-80.

16 Nomenclature for factors of the HLA system 1980. Tissue Antigens 1980;16:113-7.

17 Cesarini JP. Les mélanomes malins cutanés. Encycl Med Chir Paris. Dermatologie $1981 ; 10: 12760-8$.

18 Hodge SE, Morton LA, Tideman S, et al. Age of onset correction available for linkage analysis (LIPED). Am J Hum Genet 1979;31:761-2.
19 Ott J. Estimation of the recombination fraction in human pedigrees: efficient computation of the likelihood for human linkage studies. Am J Hum Genet 1974;26:588-97.

20 Clerget-Darpoux F, Bonaiti-Pellié C, Hochez J. Effects of misspecifying gene frequency and penetrance in lod score analysis (submitted for publication).

21 Elder DE, Goldman LI, Goldman SC, et al. Dysplastic nevus syndrome: a phenotypic association of sporadic cutaneous melanoma. Cancer 1980;46:1787-94.

22 Rahbari H, Mehregan AH. Sporadic atypical mole syndrome. Arch Dermatol $1981 ; 117: 329-31$.

23 Happle R, Traupe H, Vakilzadeh F, et al. Arguments in favor of a polygenic inheritance of precursor nevi. $J$ Am Acad Dermatol 1982;6:540-3.

24 Wallace DG, Exton LA, McLeod GRC. Genetic factor in malignant melanoma. Cancer 1971 ;27:1262-6.

25 Duggleby WF, Stoll $\mathbf{H}$, Priore R, et al. A genetic analysis of melanoma. Polygenic inheritance as a threshold trait. Am J Epidemiol 1981 ;114:63-72.

26 Ariel IM. Theories regarding the cause of malignant melanoma. Surg Gynecol Obstet 1980;150:907-17.

27 Balda BR, Hehlmann K, Cho JR, et al. Oncornavirus-like particles in human skin cancers. Proc Natl Acad Sci USA 1975;72:3697-700.

28 Debre P, Boyer B, Gioselbrecht S, et al. Genetic control of sensitivity to Moloney leukemia virus in mice. III. The three $\mathrm{H}-2$ linked $\mathrm{Rmv}$ genes are immune response genes controlling the antiviral antibody response. Eur J Immunol 1980;10:914-20.

20 Gomard E, Duprez V, Reme T. Exclusive involvement of $\mathrm{H}-2 \mathrm{D}^{\mathrm{b}}$ or $\mathrm{H}-2 \mathrm{~K}^{\mathrm{d}}$ product in the interaction between $\mathrm{T}$ killer lymphocytes and syngeneic $\mathbf{H}-2^{\mathrm{b}}$ or $\mathbf{H}-2^{\mathrm{d}}$ viral lymphomas.J Exp Med 1977;146:909-15.

Correspondence and requests for reprints to $\mathrm{Dr}$ Florence Demenais, INSERM U155, Château de Longchamp, Bois de Boulogne, 75016 Paris, France. 